\title{
Sustainable River: The role of non-structural measures and public outreach programmes
}

\author{
Nor Azilah Husin 1, Eka Mariyanti ${ }^{2}$, \\ Mazni Saad 3, Ahmad Fuad Noor ${ }^{4}$
}

1 Faculty of Business and Accountancy, Universiti Selangor, 40000, Shah Alam, Selangor, Malaysia.

${ }^{2}$ Faculty of Economics and Business,

Universitas Dharma Andalas, Padang, West Sumatra, Indonesia

${ }^{3}$ Tourism Department, Kulliyyah of Languages and Management, International Islamic University Islam Malaysia, Edu Hub Pagoh, Johor, Malaysia, ${ }^{4}$ Menteri Besar Incorporated Selangor, 40000 Shah Alam Selangor, Malaysia

nor_azilah@unisel.edu.my; ekamariyanti@yahoo.com; maznisaad@iium.edu.my; fuad@mbiselangor.com Tel: +60199877271

\begin{abstract}
The pollution level in the Klang River is high. The state government is working to address this issue. The study aims to determine the sustainability of the river through non-structural interventions and public outreach initiatives. Lembaga Urus Air Selangor (LUAS), Department of Irrigation and Drainage (DID), Klang Local Council (MPK), and Shah Alam Local Council (MBSA) provided a total of 82 accessible data. The river community and completed an adapted questionnaire. The persons in charge of river cleaning in related sectors. For the study, SPSS Version 22.00 is used to analyse data. The finding showed that Cross-sectoral Collaboration (CSC) and Public Outreach Programme (POP) significantly roles on Sustainable River Cleaning.
\end{abstract}

Keywords: sustainable river cleaning; river rejuvenation; cross-sectoral collaboration; public outreach program

eISSN 2514-751X @2021. The Authors. Published for AMER ABRA cE-Bs by e-International Publishing House, Ltd., UK. This is an open access article under the CC BY-NC-ND license (http:///creativecommons.org/licenses/by$n c-n d / 4.0)$. Peer-review under responsibility of AMER (Association of Malaysian Environment-Behaviour Researchers), ABRA (Association of Behavioural Researchers on Asians, Africans, Arabians) and cE-Bs (Centre for Environment-Behaviour Studies), Faculty of Architecture, Planning \& Surveying, Universiti Teknologi MARA, Malaysia.

DOI: https://doi.org/10.21834/ajebs.v6i19.393 


\subsection{Introduction}

Klang River flows through Kuala Lumpur and Selangor in Malaysia and eventually flows into the Straits of Malacca. It is approximately $120 \mathrm{~km}$ (75 mi) in length and drains a basin of about 1,288 km2 (497 sq mi). Klang River has 11 major tributaries.

As the river flows through Klang Valley, which is a heavily populated area of more than four million people, it is considered polluted because of deep siltation caused by human waste from informal settlers of the riverbank and even from some business establishments without septic tanks or sewage treatment plants and by soil carried by mudflows from mountains. Heavy development has narrowed specific stretches of the river to the point that it resembles a significant storm drain in some places. This contributes to flash floods in Kuala Lumpur, especially after heavy rain.

Urban rivers supply water for human survival and development and occupy an important position in maintaining ecological balance and serving social functions (Wijesiri et al., 2019). As a typical urban river, the Klang River includes household waste and municipal sewage treatment plants in Selangor. Currently, the Klang River is also being promoted as economic and cultural development in the Selangor area, and it also plays a role in tourism. However, urban expansion and industrial development caused large amounts of heavy metals and waste to enter the Klang River, resulting in severe damage to the river ecosystem. The deterioration of the urban river water environment has affected the normal development of the city and poses a severe threat to the health of the local population. The government and Selangor state have to try their best to clean the river for its sustainability. Thus, this study is to find out the initiatives such as collaboration among sectors and public outreach programmes are effective in cleaning the river.

\subsection{Literature Review}

\subsection{Theoretical studies}

Maintaining urban river quality relies on developing negotiated strategies to balance the city's social, cultural, and economic needs with local environmental constraints. For example, good management practices for urban rivers usually indicate that no physical or chemical waste will be discharged into the water if residents are environmentally conscious. In addition, river protection zones or flood risk areas will not be occupied if public institutions are active and efficient. If this ideal view were correct, it would allow for more precise interaction between the city and its rivers (Procopiuck, Rosa, Bollmann, \& de Moura, 2020).

The life history and distribution patterns of the river have been studied. The river's study has now progressed to include the production, energy flow, hydrodynamics, geomorphology, and interactions between abiotic and biotic factors (McCain, 2013). McCain (2013) reviewed previous theories related to large river ecology, and an intriguing idea associated with this study is Holling's adaptive management (AM) approach (1978).

AM approach was defined by the U.S. Department of the Interior as "a decision process that promotes flexible decision making that can be adjusted in the face of uncertainties as 
outcomes from management actions and other events become better understood" (Williams, \& Shapiro, 2007). In river operational and human factors, the AM was cited as critical in river management and restoration.

Chaos phase space theory, also known as chaotic phase space theory, explains the complicated, extensive system with high non-linear characteristics of the hydrologic system as river ecology has evolved through time. The complex system is caused by interactions with natural factors such as weather, climate, topography, and the impact of human activities such as habitat alteration, exotic species invasion, etc. The theory established four models: single-point, multi-point, lineal, and three-parameter. The model was used to explain China's frequent floods' mid-and long-term hydrologic prediction (Zhang et al., 2009). According to Zhang et al. (2009), chaotic phase space theory has a more robust non-linear mapping function and much more information in time series than traditional methods. Zhang et al. (2009) postulated that chaotic phase space theory has a more robust non-linear mapping function and much more information in time series than traditional methods. The authors concluded that the chaos phase space theory effectively explains the hydrology system for a more precise flood prediction.

\subsection{River Sustainability}

River sustainability is concerned with resource sufficiency, resilience to water-related risks, access to water supply and other services, the productive use of water, and fairness between different users and generations. Sustainable Development Goal (SDG 17) refers to the need for cross-sector and cross-country collaboration to pursue all the goals by the year 2030. It seeks to promote international trade and help developing countries increase their exports to ensure a universal rules-based and equitable trading system that is fair, open, and beneficial to all.

Research related to river sustainability mainly was carried out in the 2007-2011 period with discussions on sustainable water resource management; Vos viewer is software that helps the researcher map literature on Sustainable Rivers, Vos viewer is software that allows seeing gaps in literature reviews that were collected previously with the help of software Publish or perish seven by collecting 1000 journals relevant to river sustainability, in figure 1 Vos Viewer Overlay Visualization River Sustainability there is a blue color is the first cluster, also known as research that has not been studied much, green is the second or medium cluster. Yellow is the third cluster, which is the most potent and most studied research. And in 2021, there are not many studies that show concern for sustainable rivers, so the researchers feel that this research is vital to be conducted.

Muara Sungai Klang is one of the high economic and urban areas in Selangor, Malaysia (Haris \& Aris, 2015). The Klang River consists of about $120 \mathrm{~km}$ of river valleys from Kuala Lumpur to the Malacca Strait. The Klang River is a $120 \mathrm{~km}$ long, highly polluted river with 11 main tributaries. This pollution is caused by urbanization and industrialization (Suryadevara, Tunasamy, \& Mercy, 2019). Estimates of receiving tons of effluent and waste disposal from residential and industrial activities, both from the Langat River and the Klang River (Omar et al., 2018). Without strict regulation and mitigation of microplastic pollution 
in the environment, an abundance of microplastics can harm humans in the future (Zaki, Zaid, Zainuddin, \& Aris, 2021). Figure 2 shows the condition of the Klang river flow before cleaning the Kelang River, and the picture next to it is the condition of the Kelang River, which has been cleaned with the help of an interceptor.

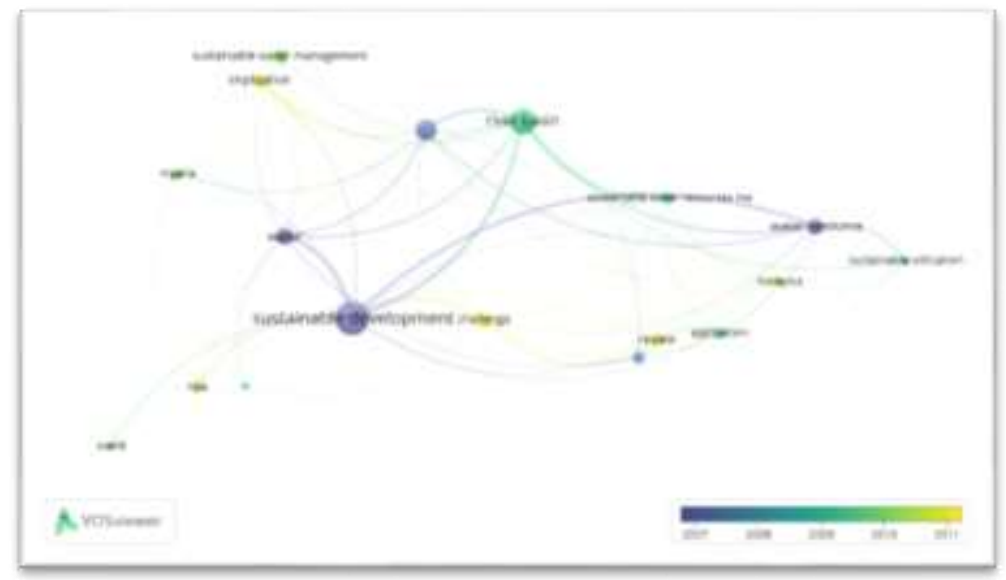

Figure 1. Vos Viewer Overlay Visualization River Sustainability

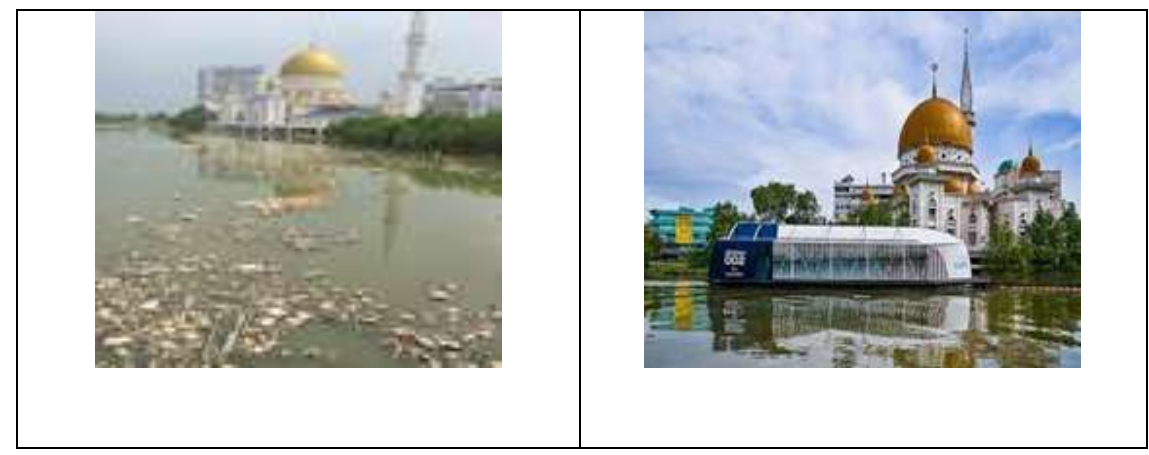

Figure 2. Klang River

\subsection{Cross-sectoral Collaboration}

This cross-sectoral collaboration section will overview the different flows in cross-sectoral collaborative research and sustainable rivers. Most studies in cross-sectoral collaboration related to the flow of inter-organizational relations research deal with various factors regarding the dynamics of partnerships (Murphy, Arenas \& Batista, 2014). In the last decade, these cross-sectoral partnerships have developed into essential instruments for 
solving complex sustainability issues (Van Huijstee et al., 2007). In this study, non-profit organizations proactively engage with businesses to solve these problems (Jamali \& Keshishian, 2008). Figure 3 shows a combination of various communities involved in effective river cleaning.

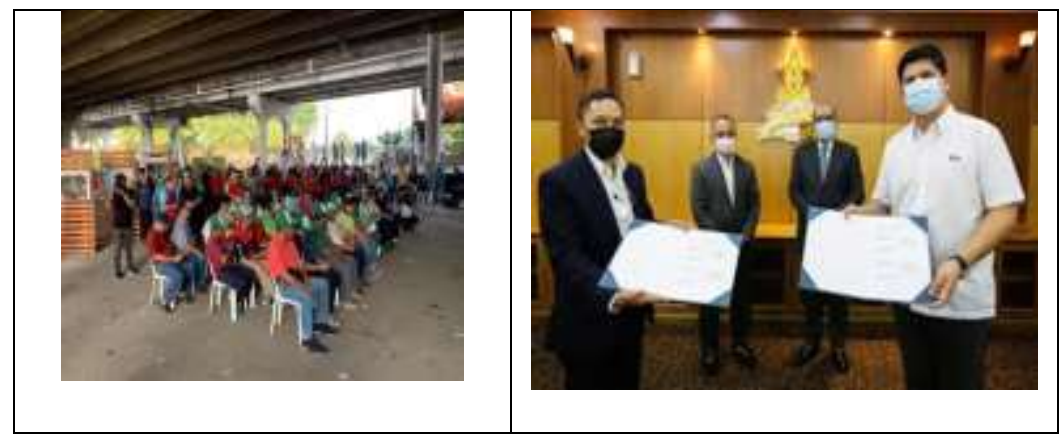

Figure 3. Cross-sectoral Collaboration

This section investigates how cross-sectoral collaboration in effective river cleaning emerged and was institutionalized and how it helps solve complex environmental problems. The research in this section is mainly based on primary documents as well as interviews administered to relevant government agencies of Lembaga Urus Air Selangor (LUAS), Jabatan Pengairan dan Saliran (JPS), and Majis Perbandaran Klang (MPK) and river community constituting a significant source of primary data for the study. Based on this argument, the researchers formulated the following hypothesis:

H1: There is a significant influence of Cross-sectoral Collaboration (CSC) on the Effective River Cleaning.

\subsection{Public Outreach Program}

While these efforts to accumulate plastic pollution are laudable, their current capacity and broad applicability are limited relative to their potential and the extent of the plastic pollution problem. Likewise, few technologies work to prevent plastic pollution leakage, and the technologies that do are limited in scope. A comprehensive approach that combines technology, policymaking, and advocacy is needed to avoid further plastic pollution and its subsequent damage to aquatic ecosystems and human health (Schmaltz et al., 2020).

Research on Public Outreach and its impact was mainly carried out in 2010-2011. This can be seen on the Vos Viewer map, which previously used the help of publishing or perishes seven could collect 950 literature related to public outreach. Vos viewer helps map the literature, such as which can be seen in Figure 4 that the yellow line shows that this research was mainly carried out in 2011 and is not related to rivers. Currently, researchers are conducting research on the Public Outreach Program related to rivers in 2021, and it seems that this research is interesting to study further. 

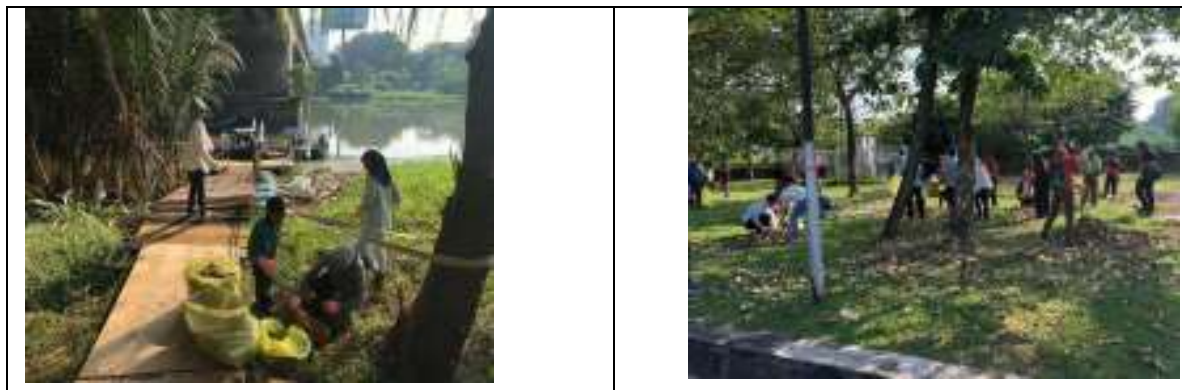

Figure 4. Public Outreach Program

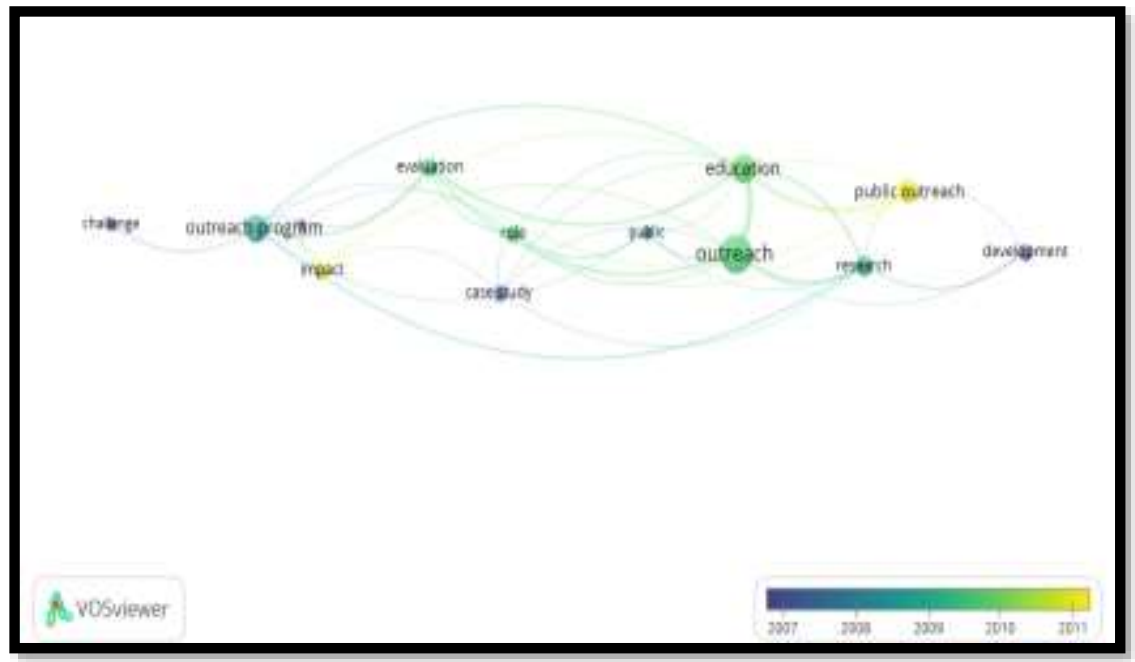

Figure 4. Overlay Visualization Public Outreach Program

The public outreach program includes an awareness program and education that will enable to change the mindset and behaviour and promote recycling programs that will eventually minimize environmental pollution. Many measures, initiatives, policies, and strategies used by the government aim to instill awareness and a sense of belonging to reduce and prevent litter. Long-term solutions, education focusing on improved understanding in developing countries can be crucial. As found in the study conducted by Sakamoto et al., 2017, education activities do not directly result in improving the riverine environment. Still, relevant actions may contribute to intermediate- to long-term increases in motivation and quality of knowledge of the people interested in environmental protection. Therefore, the researchers designed the following hypothesis: 
H2: There is a significant influence of public outreach programs on the Effective River Cleaning

\subsection{Research framework}

A research framework has been established between the independent variables and the dependent variable, illustrated in Figure 5

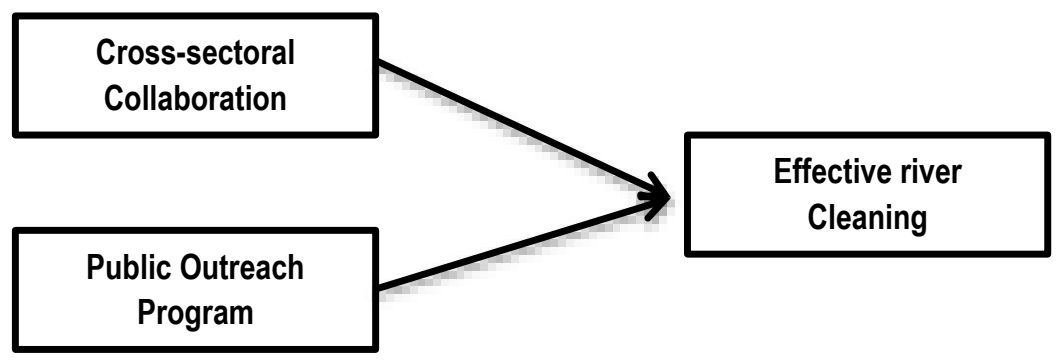

Figure 5. Research Framework

\subsection{Methodology}

\subsection{Research design}

Research design is a form of information gathering procedure and research analysis. This study focuses on two key variables central to Effective River Cleaning, namely the Crosssectoral Collaboration and Public Outreach Program to address the level of pollution in the Klang River. This study uses a quantitative research approach, which is a form of justified inquiry with fact-finding using objective measurements and statistical analysis of numerical data to understand and explain phenomena and guide practices and policies (Sundram et al., 2016).

The descriptive design focuses on collecting information to answer Effective river Cleaning through survey instruments utilizing questionnaires given to relevant government agencies Lembaga Urus Air Selangor (LUAS), Jabatan Pengairan dan Saliran (JPS), dan Majlis Perbandaran Klang (MPK), and river community constituting a significant source of primary data for the study. Several visits were made primarily at the garbage traps in the river to assess the amount of trapped waste, the presence of unpleasant odors, and the color of the water. This approach is a statistical methodology needed to analyze numerical data with the help of SPSS applications. Positivistic researchers believe that the social world consists of concrete and unchangeable realities that can be evaluated impartially. The positivist model is dominant in friendly and instructive exploration by giving importance to the use of government-approved tests and appropriate perceptions, trial review 
information, and measurable examinations (Rahman, 2017). Therefore, quantitative research methods are pretty influential.

\subsection{Data collection}

The type of research approach used in this study was quantitative research. Non-probability sampling enabled the researcher to identify the most relevant targets, to select some group of samples that represent the whole, and to identify the most favorable and potential sources of information to the study (Kothari, 2004). The purposive sampling technique is utilised to have the proper respondents. They are dealing with river cleaning, communities, and staff from three (3) state institutions directly involved in river and watershed management. They are members who have a special relationship with the phenomenon under investigation, sufficient and relevant work experience in river management. In this context, 120 participants proposed for this study questionnaire which returned 82 questionnaires, resulting in the response rate is $68.33 \%$. The study was conducted using the survey method. "Historically speaking, quantitative research has dominated educational research. Numeric data such as statistics tend to reassure researchers and laypersons alike that 'hard facts' are being unearthed about the phenomenon under study, and that is more reliable and valid." (Sundram et al., 2016). A survey instrument based on the concept of questionnaires was designed to gather primary data relating to the effectiveness river cleaning approaches survey where the questionnaire was adapted from Xanthos et al. (2017), Woldesenbelt (2018), Dauvergne, 2018, Willis et al. (2018). It consists of 20 items. The first section collects demographic information of respondents using a nominal scale. The other three areas measure respondents' perception of river cleaning effectiveness, cross-sectoral collaboration, and public outreach program. A six-point Likert scale measured the items in these sections, starting from 1 (Strongly Disagree) to 6 (Strongly Agree).

\subsection{Results}

As illustrated in Table 1 below, the demographic data sought include gender, age, educational level, working tenure, and people who reside within the study area for this research. Frequencies and percentage distributions for corresponding demographic profiles are displayed in Table 3 below

Table 1. Demographic Profiles of Respondents

\begin{tabular}{clclcc}
\hline \multicolumn{2}{c}{ PROFILE } & & FREQUENCIES & $\begin{array}{c}\text { PERCENTAGE } \\
(\%)\end{array}$ \\
\hline 1. Gender & - & Male & 41 & 50.0 \\
2. Age & - & Female & 41 & 50.0 \\
& & - & $18-30$ Years & 30 & 36.6 \\
& & - & $31-40$ Years & 37 & 45.1 \\
& & - & $41-50$ Years & 12 & 14.6
\end{tabular}




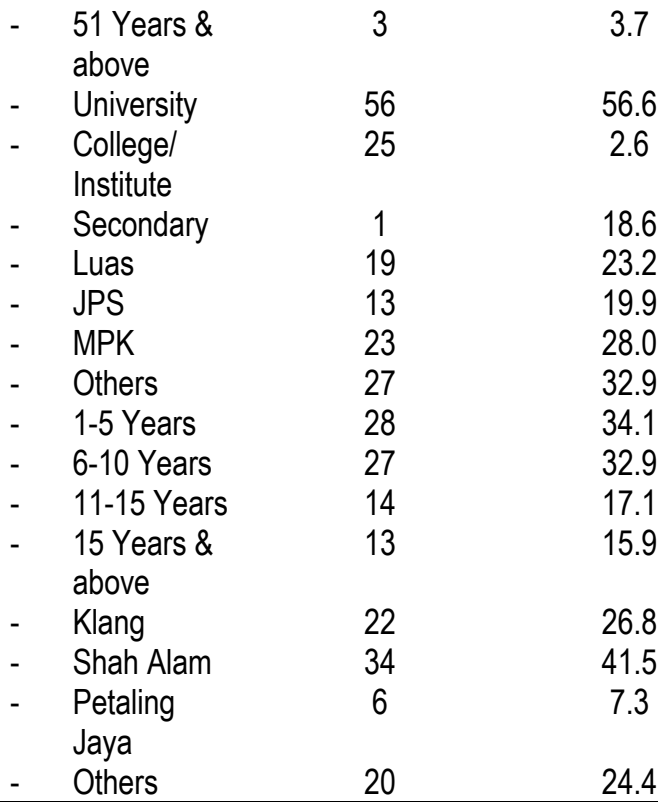

Statistical Analysis: The number of male respondents is equal to the number of female respondents. We went to survey during regular working hours in December. At this time of the year, most of the civil servants went for a long holiday break. It corresponds to the response rate of $68.3 \%$ which is 82 responded questionnaires returned, Age of Respondent Statistical Analysis Majority of the respondents belong to the age group of 40 and below, which shows that the majority of them belong to the working population and the majority of the people are young and are as a demographic dividend to the nation. For Education Level, the majority of the respondents have a higher education of at least university level, which shows that majority of them are knowledgeable enough to provide valuable responses. The majority of them belong to the working population and the educated group, which indicates that the level of education required to fill up job requirements is rising.

A total of 82 questionnaires were returned to the groups. The majority of the respondents belong to those who reside or work within the study area. At the same time, JPS has the lowest response. At the same time, the Working Tenure Majority of the respondents belong to the working tenure group of 10 years and shorter periods, which is consistent with the younger age group as depicted in the age category. This shows that most of them belong to the working population, and the majority of the people are young and are as a demographic dividend to the nation. The purpose of asking resides in the question was to find out how many of the respondents are living within Phase 1 of the SMG project, which covers the vital stretch for future riverfront development. The majority of the 
respondents live in Klang and Shah Alam, which shows that their inputs are vital for community involvement in the river cleaning activities.

\subsection{Reliability test}

Table 2 represents the variables of reliability test conducted throughout Cronbach's Alpha test to test data consistency. The scale of Cronbach's Alpha test should be more than 0.7 as it was standardized initially. The Cronbach's Alpha for the Effective River Cleaning is 0.867, 0.803 for Cross-sectoral Collaboration, and 0.902 for Public Outreach Program, confirming that they are reliable.

\begin{tabular}{lcc} 
& Table 2. Reliability Test & \\
\hline \multicolumn{1}{c}{ Variables } & Cronbach's Alpha & Item \\
\hline Effective River Cleaning & .867 & 5 \\
Cross-sectoral Collaboration & .803 & 4 \\
Public Outreach Program & .902 & 5 \\
\hline
\end{tabular}

\subsection{Regression Analysis}

This study presents that all variables must have a normal distribution. The absolute value of skewness $-/+2$ and value of kurtosis $-/+7$ were used to determine normality, and these values were considered adequate (Kline 2005). The skewness and kurtosis values in Table 3 are within the threshold value, indicating that the data is standard.

Table 4. Coefficients in the Regression Analysis

\begin{tabular}{lccccc}
\hline \multicolumn{1}{c}{ Model } & \multicolumn{2}{c}{$\begin{array}{c}\text { Unstandardized } \\
\text { Coefficients }\end{array}$} & $\begin{array}{c}\text { Standardized } \\
\text { Coefficients }\end{array}$ & $\mathbf{t}$ & Sig. \\
\hline Constant & $\mathrm{B}$ & Std Error & Beta & & \\
Cross-sectoral & 1.967 & .455 & & 4.326 & .000 \\
Collaboration & .530 & .092 & .540 & 5.738 & .000 \\
$\begin{array}{l}\text { Public Outreach } \\
\text { Program }\end{array}$ & .457 & .093 & .480 & 4.897 & .000 \\
\hline $\mathrm{R}$ & & & & & \\
$\mathrm{R}^{2}$ & & & $.742^{\mathrm{a}}$ & & \\
Adjusted R2 & & & .523 & & \\
$\mathrm{~F}$ & & .504 & & \\
Durbin Watson & & & 20.791 & & \\
\hline
\end{tabular}

a. Predictors: (Constant), Cross-sectoral Collaboration, Public Outreach Program

b. Dependent Variable: Effective River Cleaning

\subsection{Discussion}

This research aims to identify and understand the effective river cleaning approaches for the Klang River under the SMG project currently undertaken by the State. To achieve these 
objectives, the study scrutinizes the non-structural measures of Cross-sectoral Collaboration and Public Outreach on Effective River Cleaning. This study identifies and understands whether non-structural actions i.e. Cross-sectoral Collaboration and Public Outreach Program contribute to the effectiveness of river cleaning to help to reduce the amount of waste going into the river and improving the degraded water quality of the Klang River for the SMG project.

The findings support the hypothesis that Cross-sectoral Collaboration has a significant influence on the Effective River Cleaning. There is a positive significant influence on Crosssectoral Collaboration on the Effective River Cleaning to improve the degraded water quality of the Klang River. The effectiveness of river cleaning depends on how those who manage to take considerable measures. This research shows that Cross-sectoral Collaboration indeed has a significant impact towards the effectiveness of river cleaning. Cross-sectoral Collaboration helps to sustain the effectiveness of river cleaning shortly by enhancing the governance structures themselves. This is simply because Cross-sectoral Collaboration may help facilitate coordination among different sectors in the government and public sectors, ensuring continuous commitments and a sense of responsibility of various stakeholders.

The finding has shown that based on the hypothesis, there is a significant influence Public Outreach Program on the Effective River Cleaning and the hypothesis is supported. The expected result for the proposed hypothesis was that the implementation of the Public Outreach Program would improve the effectiveness of the Klang River cleaning. The Public Outreach Program is also one of the non-structural measures found to have increased the effectiveness of river cleaning. Programs such as "Hari Tanpa Plastik" and "Cintailah Sungai Kita" are effective in creating awareness, changing the mindset and behavior, and promoting recycling programs.

It is observed that the reduction in the quantity of floatable waste in the river is due to increasing awareness among the public. To increase the awareness among the people, the Public Outreach Program is the correct initiative to educate people on the importance of river cleanliness. This is supported by Willis et al. (2018) by providing litter education programs, it has significantly reduced floatable waste and is able to raise public awareness as it creates a sense of environmental responsibility in every individual.

\subsection{Conclusion}

The aim of this study is to identify and understand the practical river cleanup approach of the Cross-Sector Collaboration and Community Outreach Program to reduce the amount of sewage entering the river and improve the quality of the degraded Klang River water for the current SMG project undertaken by the State of Selangor. Based on the analysis, it can be seen that there is a significant relationship between non-structural actions, namely Cross-Sectoral Collaboration and Community Outreach Programs with River Cleaning, to help reduce the amount of waste entering the river and improve the water quality of the damaged Klang River. 
There are several suggestions for future research that could create broad results. This study involved respondents from agencies with expertise in watershed management and those who live or work in the study area. To increase the generalizability of the results, it is recommended that the samples come from upstream and downstream along the Klang River. This will result in a larger sample size. This study can also be used to cross-check findings across rivers in Malaysia. Future studies should be expanded to cover other rivers in Selangor State such as Langat River, Selangor River.

\section{Acknowledgement}

We would like to say a big thank you all the participants from cross sectoral sectors namely Lembaga Urus Air Selangor (LUAS), Department of Irrigation and Drainage (DID), Klang Local Council (MPK), and Shah Alam Local Council (MBSA) and Klang River community.

\section{Article Contribution to Related Field of Study}

This article is related to the cleanliness of the Klang River by testing the Cross-sectoral Collaboration (CSC) and Public Outreach Program (POP) on Sustainable River Cleaning.

\section{References}

Dauvergne, P. (2018). Why is global governance of plastic failing the oceans? Global Environmental Change 51 (2018) 22-31.

Haris, H., Aris, A.Z., 2015. Distribution of metals and quality of intertidal surface sediment near commercial ports and estuaries of urbanized rivers in Port Klang, Malaysia. Environ. Earth Sci. 73 (11), 7205-7218)

Kothari, C. R. (2004). Research methodology: Methods and techniques. New Age International.

Jamali, D., \& Keshishian, T. (2008). Uneasy Alliances: Lessons Learned from Partnerships Between Businesses and NGOs in the context of CSR. Journal Of Business Ethics, 84(2), 277-295.

McCain, K.N.S. (2013). Moving large river ecology from past theories to future actions: a review. Reviews in Fisheries Science, 21(1), 37-41.

Murphy, M., Arenas, D., \& Batista, J. (2014). Value Creation in Cross-Sector Collaborations: The Roles of Experience and Alignment. Journal Of Business Ethics, 130(1), 145-162. .

Omar, T.F.T., Aris, A.Z., Yusoff, F.M., Mustafa, S., 2018. Occurrence, distribution, and sources of emerging organic contaminants in tropical coastal sediments of anthropogenically impacted Klang River estuary, Malaysia. Mar. Pollut. Bull. 131, 284-293

Procopiuck, M., Rosa, A., Bollmann, H. A., \& de Moura, E. N. (2020). Socially evaluated impacts on a technologically transformed urban river. Environmental Impact Assessment Review, 84(October 2019). https://doi.org/10.1016/j.eiar.2020.106442 
Rahman, M. S. (2017). The Advantages and Disadvantages of Using Qualitative and Quantitative Approaches and Methods in Language "Testing and Assessment" Research: A Literature Review. Journal of Education and Learning, 6(1), 102.

Sakamoto, T., Shinozaki, Y., and Shirakawa, N. (2017): Nationwide investigation of citizen-based river groups in Japan: their potential for sustainable river management, International Journal of River Basin Management.

Schmaltz, E., Melvin, E. C., Diana, Z., Gunady, E. F., Rittschof, D., Somarelli, J. A., ... Dunphy-Daly, M. M. (2020). Plastic pollution solutions: emerging technologies to prevent and collect marine plastic pollution. Environment International, 144(September). https://doi.org/10.1016/j.envint.2020.106067.

Suryadevara, N., Tunasamy, K., \& Mercy, O. A. (2019). Molecular characterisation and antibiogram of water quality indicator bacteria in water samples from Klang river. Materials Today: Proceedings, 16, 1570-1580. https://doi.org/10.1016/j.matpr.2019.06.019

Sundram, V. P. K., Chandran, V. G. R., Atikah, S. B., Rohani, M., Nazura, M. S., Akmal, A. O., Krishnasamy, T., (2016). Research Methodology: Tools, Methods and Techniques. MLSCA, Selangor.

Van Huijstee, M., Francken, M., \& Leroy, P. (2007). Partnerships for sustainable development: a review of current literature. Environmental Sciences, 4(2), 75-89.

Warner, F. (2006). More sustainable participation? Multi-stakeholder platforms for integrated catchment management. Water Resource Dev 22(1):15-35.

Wijesiri, B., Liu, A., He, B., Yang, B., Zhao, X., Ayoko, G., Goonetilleke, A., (2019). Behaviour of metals in an urban river and the pollution of estuarine environment. Water Res. 164, 114911.

Williams, B. K., Szaro, R. C., \& Shapiro, C. D. (2007). Adaptive management: the US Department of the Interior technical guide. US Department of the Interior, Adaptive management working group.

Willis, K., Maureaud, C., Wilcox, C., \& Hardesty, B. D. (2018). How successful are waste abatement campaigns and government policies at reducing plastic waste into the marine environment? Marine Policy, 96, 243-249.

Woldesenbet, W.G. (2018). Collaborative governance: assessing the problem of weak cross-sectoral collaborations for the governance of Addis Ababa Rivers. Applied Water Science (2018) 8:116.

Xanthos, D., Walker, T.R. International policies to reduce plastic marine pollution from single-use plastics (plastic bags and microbeads): a review, Mar. Pollut. Bull. (2017).

Zaki, M. R. M., Zaid, S. H. M., Zainuddin, A. H., \& Aris, A. Z. (2021). Microplastic pollution in tropical estuary gastropods: Abundance, distribution and potential sources of Klang River estuary, Malaysia. Marine Pollution Bulletin, 162(June 2020). https://doi.org/10.1016/j.marpolbul.2020.111866

Zhang, L., Xia, J., Song, X., \& Cheng, X. (2009). Similarity model of chaos phase space and its application in midand long-term hydrologic prediction. Kybernetes, 38(10), 1835-1842. 